UDC 577.3

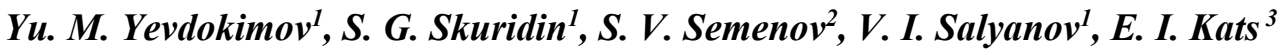

\title{
DISORDER OF DNA STRUCTURE IN QUASINEMATIC LAYERS OF "RE-ENTRANT" TWISTED PHASES
}

\author{
${ }^{1}$ Engelhardt Institute of Molecular Biology of the Russian Academy of Sciences, \\ 32 Vavilova St., Moscow, 119991, Russia. E-mail: yevdokim@eimb.ru \\ ${ }^{2}$ National Research Centre «Kurchatov Institute», \\ 1 Kurchatova Sq., Moscow, 123182, Russia \\ ${ }^{3}$ Landau Institute for Theoretical Physics of the Russian Academy of Sciences, \\ 1-a Academician Semenov Ave., Chernogolovka, 142432, Moscow Region, Russia
}

The CD spectra of double-stranded (ds) DNA dispersion particles with the "re-entrant" cholesteric structures formed in poly(ethyleneglycol)-containing solutions are compared. The high osmotic pressure of the solvent results in the dense packing DNA molecules and alteration of their secondary structure as well as a disorder of molecules in quasinematic layers of dispersion particles. Under these conditions, it is impossible to connect the adjacent ds DNA molecules by specific cross-links (nanobridges).

Key words: double-stranded DNA, liquid-crystalline dispersions of DNA, circular dichroism spectra, quasinematic layers of DNA molecules, "re-entrant" cholesteric packing of DNA, intercalation of antracycline drugs, cross-linking of DNA molecules, disorder of quasinematic layers and of DNA secondary structure.

DOI: $10.18083 /$ LCApp1.2021.2.54

\section{Ю. М. Евдокимов ${ }^{1}$, С. Г. Скуридин ${ }^{1}$, С. В. Семёнов², В. И. Салянов ${ }^{1}$ Е. И. Кац}

\section{НАРУШЕНИЕ СТРУКТУРЫ ДНК В КВАЗИНЕМАТИЧЕСКИХ СЛОЯХ «ВОЗВРАТНЫХ» ЗАКРУЧЕННЫХ ФАЗ}

\footnotetext{
${ }^{1}$ Институт молекулярной биологии им. В. А. Энгельгардта Российской академии наук, ул. Вавилова, д. 32, 119991 Москва, Россия. E-mail: yevdokim@eimb.ru

${ }^{2}$ Национальный исследовательский центр «Курчатовский Институт», пл. Курчатова, д. 1, 123182 Москва, Россия

${ }^{3}$ Институт теоретической физики им. Л. Д. Ландау Российской академии наук, пр-т Академика Семенова, д. 1-А, 142432 Черноголовка, Московская обл., Россия
}

Сопоставлены спектры КД частии дисперсий двухиепочечных молекул ДНК с «возвратной» холестерической структурой, образованных в растворах, содержсащих полиэтиленгликоль. Высокое осмотическое давление растворителя приводит к плотной упаковке молекул ДНК, изменению их вторичной структуры и нарушению упорядоченного расположения в квазинематических слоях частии дисперсии. $B$ этих условиях становится невозможным «сшивание» соседних молекул ДНК при помощи специфических полимерных хелатных комплексов (наномостиков).

Ключевые слова: двухиепочечная ДНК, жидкокристаллические дисперсии ДНК, спектры кругового дихроизма, квазинематические слои молекул ДНК, «возвратная» холестерическая упаковка ДНК, интеркаляиия антраииклиновых антибиотиков, «сшивание» молекул ДНК, изменение вторичной структуры ДНК, нарушение упорядоченного расположения ДНК в квазинематических слоях.

(c) Yevdokimov Yu. M., Skuridin S. G., Semenov S. V., Salyanov V. I., Kats E. I., 2021 


\section{Introduction}

It is well-known that linear double-stranded (ds) DNA molecules can form a number of liquidcrystalline (LC) phases at room temperature. The typical sequence of phase transitions observed upon the increase of the ds DNA concentration in a solution is the following: isotropic phase $\rightarrow$ (blue phase?) $\rightarrow$ cholesteric phase $\rightarrow$ hexagonal (columnar) phase $\rightarrow$ crystal phase [1-3].

Alongside with the LC phases, LC dispersions of nucleic acids can also be formed $[4,5]$. These dispersions can be obtained, in particular, as a result of phase exclusion of linear ds DNA molecules from aqueous-salt-poly(ethylene glycol) (PEG) solutions $[6,7]$ or mixtures of PEG with a mineral oil [8].

The packing pattern of the low- and highmolecular mass compounds as well as ds DNA molecules in bulk LC phases can be determined by various methods [9]. However, additional studies are required to determine, how DNA molecules are packed in dispersion particles obtained as a result of their phase exclusion from aqueous-salt solutions of polymers (for instance, PEG-containing solutions).

Osmotic pressure of a PEG solution defines the type of packing ds DNA molecules in dispersion particles $[7,10]$. The ds DNA dispersions are formed, when PEG concentration in a solution used for phase exclusion, exceeds a certain "critical" value $[6,11]$.

The pattern of ds DNA packing in dispersion particles can differ from the pattern typical of bulk LC phases due to the "finite size effects" [12-14]. The phase exclusion of ds DNA molecules at room temperature is accompanied by the formation of two main types of dispersion particles, namely, particles with cholesteric and hexagonal packing of molecules.

The dispersion particles with hexagonal packing of ds DNA molecules are optically inactive, whereas the particles with cholesteric packing have a very intense (abnormal) band in the circular dichroism (CD) spectrum at room temperature [15].

In the recent publication of our group it was shown that the hexagonal phase of ds DNA molecules may rather unexpectedly transform into a new optically active twisted (cholesteric-like) phase upon heating [16]. This behavior yielding to a new LC structure has been termed the "re-entrant" phenomenon. Our motivation for presenting this manuscript is the new results (see details below) which have emanated for the time elapsed after that publication [17-19].
Note also the work [20], where it was demonstrated how an appropriate selection of competing interactions of oligonucleotide's molecules results into the successful design of a "re-entrant DNA hydrogel" that melts both on heating and on cooling.

The published data allows us to suppose that depending on certain conditions of the phase exclusion (DNA molecular mass, osmotic pressure and temperature of solvent) a multiplicity of "re-entrant" DNA phases can exist.

However, answering the question about interrelation between the DNA secondary structure and the efficiency of the "re-entrant" phase's formation requires additional studies.

In the present work, we focus our attention on the comparison of the CD spectra of ds DNA "reentrant" phases formed at different osmotic pressure of PEG-containing solutions. We also analyze modifications of these spectra as a result of the interaction of antibiotic molecules with DNA nitrogen base pairs and the formation of cross-links between adjacent DNA molecules.

Our approach is based on the consideration of the following essential factors.

1) Phase exclusion of linear ds DNA with the intact secondary structure (B-form) from aqueous-salt PEG-containing solutions results in the formation of LC particles. The reduction of the distance between ds DNA molecules packed in quasinematic layers of dispersion particles at high osmotic pressure of the solution may be accompanied by the distortion of the DNA secondary structure.

2) Some external compounds can be inserted (intercalated) between the nitrogen base pairs only of B-form of DNA molecules. In this case, an additional abnormal band can appear in the CD spectrum in the region of absorption of intercalator chromophores. Possible distortion of the ds DNA secondary structure at the formation of the "re-entrant" phase may be accompanied by the alteration of the shape of this band or its disappearance.

3) At certain spatial arrangement of adjacent ds DNA molecules with the intact secondary structure in quasinematic layers of dispersion particles, it is possible to form the cross-links between these molecules. An alteration of the DNA secondary structure or an appearance of a disorder in distance between these molecules at the formation of a "re-entrant" phase makes the cross-links and the change of the CD spectrum shape impossible. 
Thus, the registration of the $\mathrm{CD}$ spectra of aqueous-salt PEG-containing solutions under various conditions will allow us to determine both the DNA secondary structure and the DNA molecular packing in quasinematic layers of dispersion particles of the "re-entrant" phases.

In what follows, we will show that the optical properties of "re-entrant" cholesteric phases depend on the mean distance between DNA molecules and the peculiarities of the DNA secondary structure.

These new observations and their interpretation is the topic of our work.

\section{Materials and methods}

\section{Preparation of ds DNA LC dispersions}

A calf thymus and chicken blood erythrocytes depolymerized ds DNAs ("Sigma", USA and "Reanal", Republic of Hungary respectively) with a molecular mass of $<1,0 \times 10^{6}$ Da were used after additional purification. The molecular mass of DNA after purification and depolymerization was determined by electrophoresis in a $1 \%$ agarose gel.

Poly(ethylene glycol) ("Sigma" (BioUltra), USA) sample with a molecular mass of 4,000 Da and anthracycline antibiotic doxorubicin (DOX; "Sigma", USA) were used without additional purification.

DNA and DOX concentrations in the aqueoussalt solutions were determined spectrophotometrically using the known values of the molar extinction coefficients $\left(\varepsilon_{258.4}=6,600 \mathrm{M}^{-1} \cdot \mathrm{cm}^{-1}\right.$ and $\varepsilon_{480}=11,500 \mathrm{M}^{-1} \cdot \mathrm{cm}^{-1}$, respectively) [21,22].

Solutions of DNA, DOX, $\mathrm{NaCl}$ and $\mathrm{CuCl}_{2}$ were prepared in $0,002 \mathrm{M} \mathrm{Na}^{+}$-phosphate buffer $(\mathrm{pH} \sim 7,0)$.

Initial aqueous-salt solution of PEG $(0,3 \mathrm{M}$ $\mathrm{NaCl}, \mathrm{C}_{\text {PEG }}=600 \mathrm{mg} \cdot \mathrm{ml}^{-1}$ ) was prepared by dissolving the weighed portions of $\mathrm{NaCl}$ and $\mathrm{PEG}$ in $0,002 \mathrm{M}$ $\mathrm{Na}^{+}$-phosphate buffer $(\mathrm{pH} \sim 7,0)$.

The ds DNA dispersions in aqueous-salt solutions of PEG with the cholesteric $\left(C_{\mathrm{PEG}} 120-200 \mathrm{mg} \cdot \mathrm{ml}^{-1}\right)$ or the hexagonal $\left(\mathrm{C}_{\mathrm{PEG}} 240-290 \mathrm{mg} \cdot \mathrm{ml}^{-1}\right)$ packing of the DNA molecules in the dispersion particles were prepared at room temperature according to the phase exclusion (condensation) technology described previously [23]. According to this method, equal volumes of aqueous-salt solutions, one of which contained DNA, and the other contained PEG (concentration of DNA and PEG in solutions were twice as high as the desired final value) were mixed, and intensively stirred during
$1 \mathrm{~min}$. The resulting mixture was left at room temperature for $1 \mathrm{~h}$ to complete the formation of the DNA dispersion. After the formation, the initial ds DNA dispersions were heated to $80{ }^{\circ} \mathrm{C}$ and cooled to room temperature. Hence, the DNA dispersions formed as the result of this "thermal training" [24, 25] were used in the experiments.

The DNA concentration in the studied PEGcontaining solutions was 10 and $30 \mu \mathrm{g} \cdot \mathrm{ml}^{-1}$.

\section{Optical measurements}

The absorption and the CD spectra were recorded with Cary 100 Scan spectrophotometer ("Varian", USA) and with SCD-2 portable dichrometer (produced by Institute of Spectroscopy of the Russian Academy of Sciences, Moscow, Troizk), respectively. The CD results are reported as $\Delta \mathrm{A}=\mathrm{A}_{\mathrm{L}}-\mathrm{A}_{\mathrm{R}} ; \Delta \mathrm{A}$ is the difference in the absorption between the left and the right polarized light at wavelength $\lambda$ [15]. In all cases, the rectangular quartz cells ("Hellma" 100 QS, Germany) with a path length of $1 \mathrm{~cm}$ were used.

The temperature in the temperature-controlled compartment of the dichrometer in the range of 20 $80{ }^{\circ} \mathrm{C}$ was set by the "Temperature control" program, which is the part of the dichrometer's software. After the required temperature was set, a cell containing 2 $\mathrm{ml}$ of DNA dispersion was heated for $10 \mathrm{~min}$ in the temperature controlled compartment, and the registration of the CD was performed. The CD spectra of all the investigated solutions were recorded in the absorption region of both DNA and DOX.

\section{Theoretical calculations of the CD spectra of ds DNA $L C$ dispersion particles}

The influence of the extent of disorder of ds DNA molecule's in the quasinematic layers of dispersion particles on their optical properties has been presented in [26], where this effect (see, below) was studied in the context of the theory of electromagnetic wave absorption by large molecular aggregates.

\section{Results and discussion}

\section{The formation of the DNA "re-entrant" cholesteric phases}

One of the most useful and reliable method of determining the type of linear ds DNA molecule packing within small-size particles at their small concentration $\left(5-30 \mu \mathrm{g} \cdot \mathrm{ml}^{-1}\right)$ in solutions is the circular dichroism [15]. 
The DNA dispersions have been formed as the result of phase exclusion of these molecules when aqueous-salt solutions of DNA were mixed with aqueous-salt solutions of PEG [19].

Poly(ethylene glycol) is a synthetic, chemically neutral, optically inactive, isotropic compound (polymer) that does not possess a CD spectrum.

The experimentally measured CD spectra of the initial linear ds DNA molecules and ds DNA LC dispersions in an aqueous-salt PEG-containing solution
$\left(\mathrm{C}_{\mathrm{PEG}}>\mathrm{C}^{\mathrm{cr} .}{ }_{\mathrm{PEG}}\right)$ are presented in Fig. 1 (curves 2-5, respectively).

Curve 1 in Fig. 1 is typical of the linear ds DNA B-form. In the interval of PEG concentrations up to $110 \mathrm{mg} \cdot \mathrm{ml}^{-1}$, the shape of the CD spectra is unchanged, which shows that the ds DNA in aqueoussalt PEG-containing solutions conserves the parameters of the linear B-form. This was confirmed by the results of small-angle X-ray scattering (SAXS) [17] of ds DNA pellets obtained under these conditions.

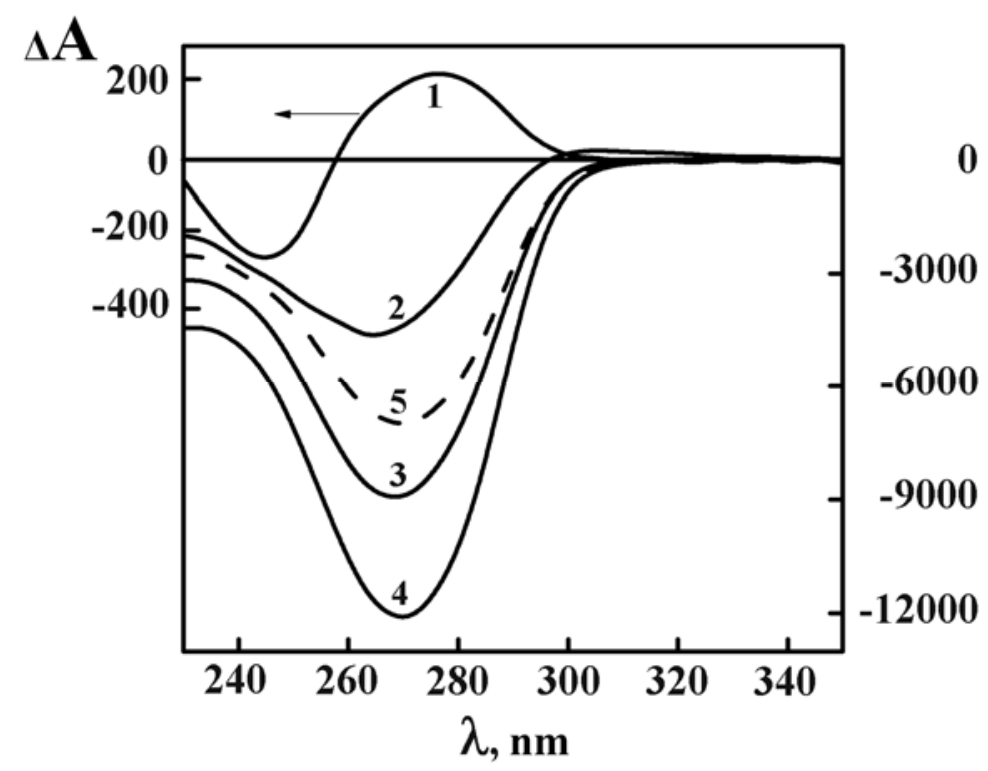

Fig. 1. The CD spectra of the aqueous-salt solution of linear B-form DNA (curve 1, left ordinate) and LC dispersions formed at room temperature as a result of phase exclusion DNA molecules from aqueous-salt solutions with different concentrations of PEG (curves 2-5, right ordinate):

$$
\begin{gathered}
1-\mathrm{C}_{\mathrm{PEG}}=0 ; 2-\mathrm{C}_{\mathrm{PEG}}=120 \mathrm{mg} \cdot \mathrm{ml}^{-1} ; 3-\mathrm{C}_{\mathrm{PEG}}=130 \mathrm{mg} \cdot \mathrm{ml}^{-1} ; \\
4-\mathrm{C}_{\mathrm{PEG}}=170 \mathrm{mg} \cdot \mathrm{ml}^{-1} ; 5-\mathrm{C}_{\mathrm{PEG}}=200 \mathrm{mg} \cdot \mathrm{ml}^{-1} \\
\mathrm{C}_{\mathrm{DNA}}=30 \mu \mathrm{g} \cdot \mathrm{ml}^{-1}, 0,3 \mathrm{M} \mathrm{NaCl}+0,002 \mathrm{M} \mathrm{Na}-\text { phosphate buffer. } \\
\Delta \mathrm{A}=\left(\mathrm{A}_{\mathrm{L}}-\mathrm{A}_{\mathrm{R}}\right) \times 10^{-6} \text { optical units, } \mathrm{L}=1 \mathrm{~cm}, \mathrm{~T}=22^{\circ} \mathrm{C} .
\end{gathered}
$$

The increase in PEG concentration in the interval from $120 \mathrm{mg} \cdot \mathrm{ml}^{-1}$ to $170 \mathrm{mg} \cdot \mathrm{ml}^{-1}$ is accompanied by phase exclusion of ds DNA from PEG-containing aqueous-salt solutions and by the appearance of an intense negative band in the $\mathrm{CD}$ spectrum in the region, where the DNA nitrogen bases absorb $\left(\lambda_{\max } \sim\right.$ $270 \mathrm{~nm}$, curves 2-4).

The growth of the amplitude of this band (without a change in shape of the CD spectra) is conditioned by a rise in the number of ds DNA dispersion particles (from 0 up to $\sim 100 \%$ ) in the solution. Under the conditions used, the single-stranded (or denatured) DNA does not condense and cannot go into the com- position of dispersion particles. Note that a conventional aggregation of DNA molecules can be accompanied by an appearance of low-intensity band in the CD spectrum of these aggregates but the reasons for its appearance remain unclear.

Theoretical calculations [26] show that the appearance of the intense (abnormal) band in the CD spectrum of ds DNA dispersions (Fig. 1) univocally testifies to the macroscopic spatially twisted packing of neighboring nitrogen bases in the content of LC dispersion particles. In the case of linear ds DNA molecule (B-form), nitrogen bases are rigidly fixed at $90^{\circ}$ with respect to the long axis of the DNA. 
The twisted structure of nitrogen bases means the twisted location of neighboring linear rigid ds DNA molecules. The ordered packing of neighboring ds DNA molecules in the structure of LC dispersion particles followed from SAXS results and their spatial twist follows from ds DNA "fingerprint" texture typical of classical cholesterics [17]. That is why we term the obtained dispersions as DNA "cholesteric liquid-crystalline dispersions" (CLCDs) or DNA cholesterics.

At room temperature, phase exclusion of linear ds DNA molecules with the "standard" molecular mass is accompanied by the formation of CLCDs, which possesses an intense (abnormal) band in the CD spectrum located in the region of DNA nitrogen bases absorption.

The decrease in the amplitude of the abnormal band in the CD spectra down to the zero value, observable at increase in PEG concentration (Fig. 1, curve 5), testifies about unwinding of spatial helical structure of the dispersion particles.

The formation of DNA LC dispersions in PEG solutions with $\mathrm{C}_{\mathrm{PEG}} 170-200 \mathrm{mg} \cdot \mathrm{ml}^{-1}$ results in a decrease in the amplitude of the band at $\lambda_{\max } 270 \mathrm{~nm}$ in the CD spectra (curve 5).

The formation of DNA LC dispersions in PEG solutions with $\mathrm{C}_{\mathrm{PEG}}>220 \mathrm{mg} \cdot \mathrm{ml}^{-1}$ does not result in the appearance of an intense band in the CD spectrum despite the fact that under these conditions, the concentration of dispersion particles is constant and equals $\sim 100 \%$.

Besides, the SAXS data [17] of phases that were formed as a result of the low-speed sedimentation of ds DNA dispersion particles under different PEG concentrations demonstrate the dense packing of the ds DNA molecules in dispersion particles. At PEG concentration between $120 \mathrm{mg} \cdot \mathrm{ml}^{-1} \leq \mathrm{C}_{\mathrm{PEG}} \leq 220 \mathrm{mg} \cdot \mathrm{ml}^{-1}$, the mean distance (d) between ds DNA molecules varies from 3,8 to $2,8 \mathrm{~nm}$; whereas at concentration $220 \mathrm{mg} \cdot \mathrm{ml}^{-1} \leq \mathrm{C}_{\mathrm{PEG}} \leq 300 \mathrm{mg} \cdot \mathrm{ml}^{-1}$, the $\mathrm{d}$ value only slightly decreases (from 2,8 to $2,4 \mathrm{~nm}$ ).

At high osmotic pressure of PEG solutions ( $\mathrm{C}_{\mathrm{PEG}} \sim$ 240-300 $\mathrm{mg} \cdot \mathrm{ml}^{-1}$ ), the packing pattern can be described as an unidirectional hexagonal alignment of ds DNA molecules or as a hexagonal packing with the parallel (nematic-like) alignment of orientationally ordered ds DNA quasinematic layers. The hexagonal packing of ds DNA molecules does not result in an appearance of an abnormal band in the CD spectrum [1].

Hence, at room temperature the registration of the $\mathrm{CD}$ spectrum in the region of absorption of the nitrogen bases allows one to estimate the details of the spatial structure of the ds DNA LC dispersion particles.

However, it is well-known that the heating of CLCDs of ds DNA results in a decrease in the abnormal band amplitude in the CD spectra up to a zero value. Despite the increase in temperature, the osmotic pressure of the PEG-containing solution remains high. The ds DNA molecules cannot "leave" the limited physical volume of CLCDs particles, and separation of ds DNA chains in these particles is impossible for steric reasons. The disappearance of the abnormal band amplitude in the CD spectra of CLCDs corresponds to the transition to a structure with a distorted location of the neighboring DNA molecules within the particles. This is known as the "CD melting" of the spatial structure of CLCDs [19].

The heating of dispersions formed at $\mathrm{C}_{\mathrm{PEG}} \geq$ $220-240 \mathrm{mg} \cdot \mathrm{ml}^{-1}$ is accompanied by an unexpected optical effect, i.e., an intense negative band in the CD spectra arises for all ds DNA dispersions, which did not possess such a band at room temperature. This band suggests a formation of a twisted structure with the orientationally helically ordered DNA nitrogen bases.

Therefore, the DNA dispersions obtained at high PEG concentrations can be transformed, by a rise in the solution temperature, into a new structure that is characterized by an intense band in the CD spectrum. Also, the amplitude value of this band for these dispersions is essentially higher than that of the values shown in Fig. 1.

The curves characterizing the change in the abnormal band amplitudes for all ds DNA LCDs under their heating and cooling are shown in Fig. 2.

Curve 1 on this phase diagram shows that at room temperature two different modes of packing of semi-flexible linear ds DNA molecules are possible.

At osmotic pressure of a solution from 4 up to $11 \mathrm{~atm}$ there is spatially twisted (cholesteric) packing of DNA molecules in dispersion particles which is easily detected on occurrence of an abnormal band in the CD spectrum in the region of absorption of DNA nitrogen bases. The particles of dispersions formed at osmotic pressure more $11 \mathrm{~atm}\left(\mathrm{C}_{\mathrm{PEG}} \sim 240-300 \mathrm{mg} \cdot \mathrm{ml}^{-1}\right)$ practically have no abnormal band in the $\mathrm{CD}$ spectrum in the region of absorption of DNA nitrogen bases. The absence of this band in the CD spectra of dispersions obtained at room temperature of a solution shows that there are different packing modes of ds DNA molecules in dispersion particles. 


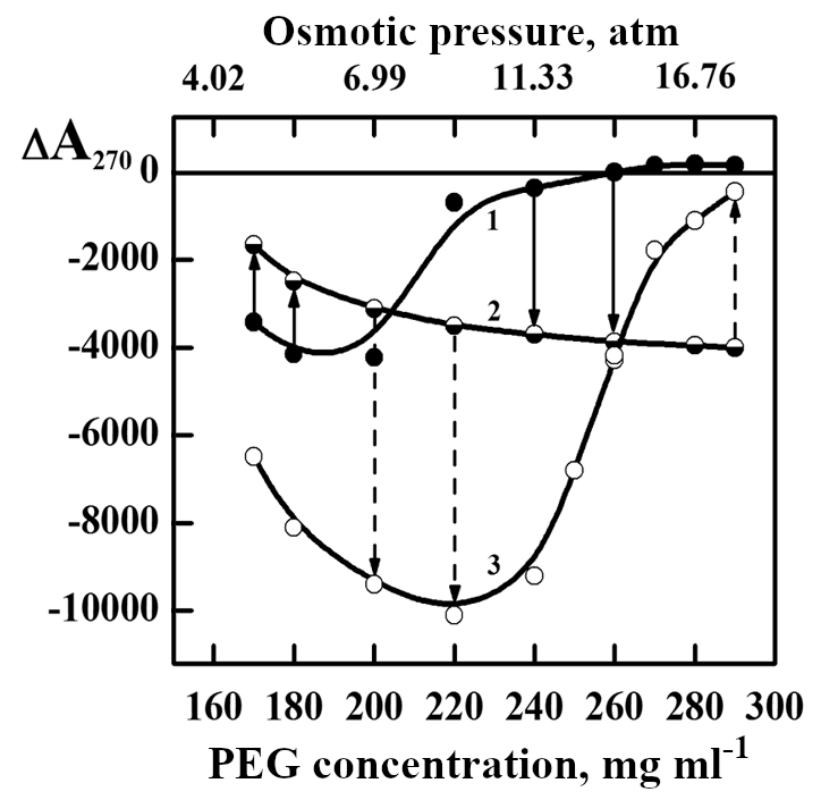

Fig. 2. The dependence of the amplitude of the abnormal band $(\Delta \mathrm{A})$ in the $\mathrm{CD}$ spectra $(\lambda=270 \mathrm{~nm})$ of ds DNA dispersions formed at room temperature (curve 1), heated to $80{ }^{\circ} \mathrm{C}$ (curve 2 ) and cooled to room temperature (curve 3 ) on $\mathrm{PEG}$ concentration.

$\mathrm{C}_{\mathrm{DNA}}=10 \mu \mathrm{g} \cdot \mathrm{ml}^{-1}, 0.3 \mathrm{M} \mathrm{NaCl}+0.002 \mathrm{M} \mathrm{Na}^{+}$-phosphate buffer. $\Delta \mathrm{A}_{270} \times 10^{-6}$ optical units, $\mathrm{L}=1 \mathrm{~cm}$.

Arrows show the direction of the $\mathrm{CD}$ band amplitude change at temperature increase from 22 to $80{ }^{\circ} \mathrm{C}$ and broken lines - at temperature decrease from 80 to $22^{\circ} \mathrm{C}$

Besides, the increase and the subsequent decrease in temperature are accompanied by different optical effects, depending on PEG osmotic pressure. For instance, at PEG osmotic pressures below $11 \mathrm{~atm}$, the abnormal band increases (curve 3) upon cooling, whereas at PEG osmotic pressures exceeding $11 \mathrm{~atm}$ one observes a tendency to partial recovery of the initial abnormal optical activity of the LCD. Figure 2, curve 3 shows behavior after cooling of the solutions from 80 to $22{ }^{\circ} \mathrm{C}$. Note that the intense negative abnormal band in the CD spectra of ds DNA dispersions (induced by a temperature rise from 22 to $80{ }^{\circ} \mathrm{C}$, Fig. 2, curve 2) does not go back to the initial values. Such behavior seems to be quite natural for first-order phase transitions, at which the existence of metastable structures (and hysteresis) is possible.

The sharp increase in the optical activity of the DNA dispersion particles upon a temperature rise looks like as a phase transition. It manifests a change in the hexagonal structure of the DNA dispersion particles. This means that the heating of LC dispersion particles with hexagonal ordering of neighboring ds
DNA molecules in quasinematic layers is accompanied by the appearance of optical activity in these particles.

It is necessary to note that the general shape of the shown phase diagram is typical for all semi-flexible linear ds DNA molecules (molecular mass $\leq 1 \times 10^{6} \mathrm{Da}$ ) used for the formation of dispersions. However, the particular details of the diagram (the amplitude of the observable effect and the position of its minimum) depend on molecular mass, nucleotide content, DNA concentration, and, apparently, on a temperature variation history of the dispersion samples.

As abnormal band in the CD spectrum in the region of absorption of the nitrogen bases $(\lambda \sim 270 \mathrm{~nm})$ reflects the helical (cholesteric) packing of quasinematic layers of ds DNA molecules [27], it is possible to think that the heating of particles with initial hexagonal packing of ds DNA molecules results in the appearance of a new helically twisted structure of these dispersions. This new structural state of DNA molecules in dispersion particles has been termed the "re-entrant" cholesteric in our work [17]. 
Thus, at the heating of dispersion particles with hexagonal packing of ds DNA molecules the phase transition hexagonal $\rightarrow$ "re-entrant" cholesteric packing takes place.

\section{Few remarks about "re-entrant" phases}

A system is said to be exhibiting "re-entrant" phase transitions (RPT) if a monotonic variation of any thermodynamic field results in two (or more) phase transitions and attains a state, which is macroscopically similar to the initial state or the system reenters the original state.

The phenomenon of RPT continues to attract interest of researchers, and observed in amazingly diverse systems e.g., binary gases, liquid mixtures of ferroelectrics, organometallic compounds, superconductors, aqueous electrolytes, etc.

Formation of "re-entrant" phases of low molecular mass compounds has been known in physics and chemistry for more than hundred years (see review [28]). In the case of liquid crystals of low-molecular mass compounds, formation of "re-entrant" phase at atmospheric pressure was discovered in 1975 by P.E. Cladis [29] (see also [30]).

The discovery of "re-entrant" behavior in liquid crystals has resulted in extensive experimental and theoretical studies of this intricate phenomenon. Much of the experimental work has been devoted to the synthesis of "re-entrant" systems, investigation of their phase diagrams (as a function of temperature, pressure and composition) and measurements of orientational order and its change at phase transitions. The main concern of theoretical work has been to understand the microscopic origin and the true nature of RPT.

Various features of this phenomenon in case of different compounds and different conditions attract attention of scientific community [31-39].

The challenging problem in this area of physics is to find the relations between spatial structure of low molecular mass compounds and efficiency of formation of "re-entrant" phases $[9,40]$.

Taking into account that shapes of the curves shown in Fig. 2 depend on molecular mass of the ds DNA molecules, their nitrogen bases content and, probably, "temperature treatment history" of sample, we can expect the multiplicity of the "re-entrant" cholesteric phases.

The main question at this point is: "How does one study the molecular ordering quasinematic layers of ds DNA molecules and their secondary structure in the "re-entrant" cholesteric phases?" The answer to this question is important, because new phases are formed at small distances between ds DNA molecules and they do not possess the "fingerprint" textures typical of classical cholesterics.

Intercalation of doxorubicin molecules between nitrogen base pairs of DNA molecules in spatially twisted phases

At the beginning, we study peculiarities of the secondary structure of DNA molecules in particles of the dispersions formed at different solution osmotic pressure and treated with anthracycline group antibiotic - doxorubicin (DOX).

This antibiotic is analogue of the wellinvestigated antibiotic - daunomycin (DAU); the theoretically calculated $\mathrm{CD}$ spectra of cholesteric dispersion particles formed by (DAU-DNA) complexes are presented in paper [19].

Structural components of anthracycline antibiotics are aglycone (anthracyclione) and sugar.

These antibiotics are water-soluble, lowmolecular substances with reactionable oxygen atoms at anthracycline aglycone (Fig. 3).

Antibiotics of anthracycline line have absorption bands both in UV and visible region of spectrum; one band is located in the wave length interval of 200$300 \mathrm{~nm}$, the other one is in the area of $400-600 \mathrm{~nm}$ [41].

At the addition of ds DNA molecules to anthracycline antibiotics, the long-wave band is shifted to $20-30 \mathrm{~nm}$ (depending on antibiotic structure) aside long waves (bathochromic shift) and its intensity decreases (hypochromic effect). The hypochromic effect in antibiotic absorption band at the presence of ds DNA reflects polarity reduction of antibiotic chromophore environment at its binding to DNA, which is caused by intercalation of antibiotic chromophore between nitrogen base pairs of DNA molecule.

In DNA complex with anthracyclines, the flat part of antibiotic chromophore settles down approximately parallel to the plane of pairs of DNA nitrogen bases, i.e. perpendicularly to the long axis of double helix. According to this model, antibiotic chromophore intercalates between DNA nitrogen base pairs on the side of a narrow groove of double helix. 
<smiles>[R2]OC1=CC(O)C([R])(O)Cc2c(O)c3c(c(O)c21)C(=O)c1cccc(OC)c1C3=O</smiles>

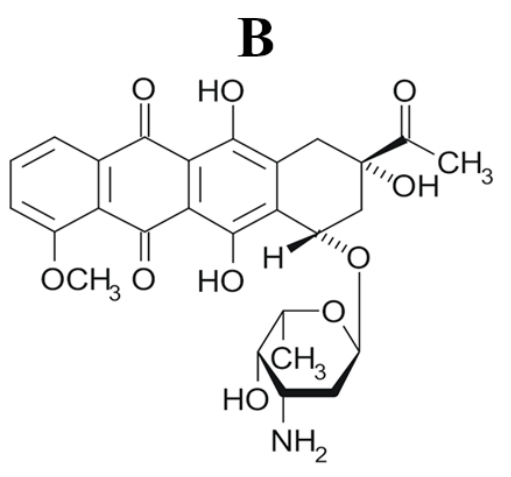

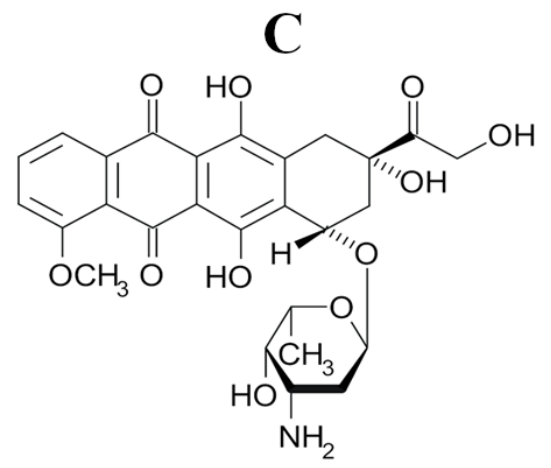

Fig. 3. Panel $A$-structure of aglycone of anthracycline compounds; panels $B$ and $C$-structures of DAU and DOX, respectively

There are two important principal physical effects caused by the intercalation of anthracycline antibiotics between DNA nitrogen base pairs:

i) partial unwinding of nitrogen base pairing of ds DNA; the unwinding angle is twice less in comparison with the angle typical of ethydium bromide;

ii) increase in the counter length and rigidity of ds DNA molecule at binding with antibiotic molecule.

These changes in the ds DNA structure that take place at intercalation of anthracycline antibiotics show that the DNA molecule has only certain (limited) number of sites on which the intercalation of these compounds occurs.

The binding constants of anthracycline antibiotics are equal to about $10^{6} \mathrm{M}^{-1}$ in $0,1 \mathrm{M}$ buffer ( $\mathrm{pH} 7.0$, $20{ }^{\circ} \mathrm{C}$ ) with one drug molecule bound per six phosphate groups at maximum binding [42-44].

Hence, for the formation of intercalation complex between anthracycline antibiotics and linear ds DNA molecules it is required that the DNA secondary structure must fit physical parameters of B-form. It is related to the fact that hydration of B-form of DNA molecules changes the distance between nitrogen base pairs. In own turns, the intercalation of anthracyclines between the nitrogen base pairs leads to their partial unwinding, and increase the effective length the DNA of the ds-DNA.

Thus, the above mentioned data show that depending on conditions (source of nucleic acid, ionic strength and $\mathrm{pH}$ value of solution), anthracycline antibiotics can form two types of complexes with ds DNA molecules, i.e., classical intercalation complex at low drug concentration and nonclassical ("external") complex at higher extent of binding to DNA. In the first case, anthracycline molecules, for instance DOX, are rigidly fixed between the base pairs of ds DNA and synthetic polynucleotides only of the B-family.

It is important to note that at formation of intercalation complex with ds DNA molecules, chemically active oxygen atoms in positions 5, 6 or 11, 12 of anthracycline antibiotics (Fig. 3) become practically inaccessible for different chemical and electrochemical reactions even in aqueous-salt solutions (in particular, for the chelate formation). In contrast, these oxygen atoms of anthracyclines are available for various chemical reactions in the case of formation of "external" complexes of with both ds DNA and ds RNA molecules. 
Besides, in CD spectra of anthracyclines there are low-intensity negative band at $\lambda \sim 300 \mathrm{~nm}$ and two low-intensity $\left(\Delta \varepsilon \sim 2-3 \mathrm{M}^{-1} \cdot \mathrm{cm}^{-1}\right)$ positive bands at $\lambda \sim 340 \mathrm{~nm}$ and at $\lambda \sim 470 \mathrm{~nm}$. Upon binding to linear ds DNA, the amplitude of the negative band at $\lambda \sim 300 \mathrm{~nm}$ increases. The peak at $470 \mathrm{~nm}$ is red shifted by approximately $20-25 \mathrm{~nm}$. The extent of the red shift of peak at $340 \mathrm{~nm}$ in the presence of DNA, however, depends on anthracycline structure $[42,43]$.

It is instructive to compare the DOX intercalation of the "classic" DNA cholesteric dispersion particles with the intercalation of their "re-entrant" counterpart (see Fig. 4, $A$ and Fig. 4, $B$ ).
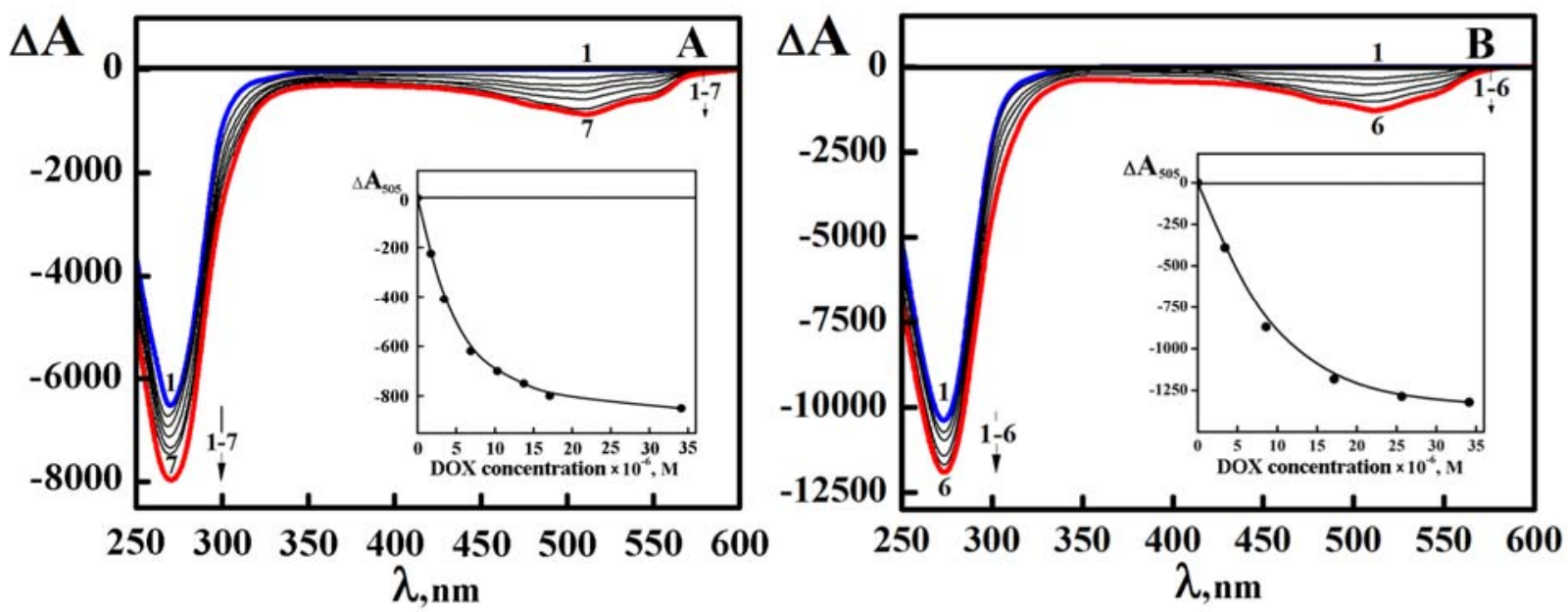

Fig. 4. The CD spectra of the DNA dispersions with cholesteric $(\boldsymbol{A})$ and "re-entrant" cholesteric $(\boldsymbol{B})$ packings of molecules treated by DOX.

$\boldsymbol{A}$ : Curve 1 - the $\mathrm{CD}$ spectrum of initial cholesteric dispersion heated from 22 to $80{ }^{\circ} \mathrm{C}$ and cooled down to $22^{\circ} \mathrm{C}$; curves 2-7 - the CD spectra after treatment of cholesteric dispersion by DOX:

$2-\mathrm{C}_{\mathrm{DOX}}=1.72 \times 10^{-6} \mathrm{M} ; 3-\mathrm{C}_{\mathrm{DOX}}=3.44 \times 10^{-6} \mathrm{M} ; 4-\mathrm{C}_{\mathrm{DOX}}=5.17 \times 10^{-6} \mathrm{M}$;

$5-\mathrm{C}_{\text {DOX }}=6.12 \times 10^{-6} \mathrm{M} ; 6-\mathrm{C}_{\text {DOX }}=17.18 \times 10^{-6} \mathrm{M} ; 7-\mathrm{C}_{\text {DOX }}=34.14 \times 10^{-6} \mathrm{M}$.

$\mathrm{C}_{\mathrm{DNA}}=10 \mu \mathrm{g} \cdot \mathrm{ml}^{-1}, \mathrm{C}_{\mathrm{PEG}}=170 \mathrm{mg} \cdot \mathrm{ml}^{-1}, 0.3 \mathrm{M} \mathrm{NaCl}+0.002 \mathrm{M} \mathrm{Na}^{+}$-phosphate buffer.

$\Delta \mathrm{A}=\left(\mathrm{A}_{\mathrm{L}}-\mathrm{A}_{\mathrm{R}}\right) \times 10^{-6}$ optical units, $\mathrm{L}=1 \mathrm{~cm}$

$\boldsymbol{B}$ : Curve 1 - the CD spectrum of the DNA "re-entrant" cholesteric phase obtained after heating and cooling the dispersion with hexagonal packing of molecules; curves $2-6$ - the CD spectra after treatment of "re-entrant" cholesteric phase by DOX:

$2-\mathrm{C}_{\text {DOX }}=1.72 \times 10^{-6} \mathrm{M} ; 3-\mathrm{C}_{\text {DOX }}=3.44 \times 10^{-6} \mathrm{M} ; 4-\mathrm{C}_{\mathrm{DOX}}=6.89 \times 10^{-6} \mathrm{M}$; $5-\mathrm{C}_{\mathrm{DOX}}=13.74 \times 10^{-6} \mathrm{M} ; 6-\mathrm{C}_{\mathrm{DOX}}=34.14 \times 10^{-6} \mathrm{M}$.

$\mathrm{C}_{\mathrm{DNA}}=10 \mu \mathrm{g} \cdot \mathrm{ml}^{-1}, \mathrm{C}_{\mathrm{PEG}}=240 \mathrm{mg} \cdot \mathrm{ml}^{-1}, 0.3 \mathrm{M} \mathrm{NaCl}+0.002 \mathrm{M} \mathrm{Na}^{+}$-phosphate buffer. $\Delta \mathrm{A}=\left(\mathrm{A}_{\mathrm{L}}-\mathrm{A}_{\mathrm{R}}\right) \times 10^{-6}$ optical units, $\mathrm{L}=1 \mathrm{~cm}$

In both cases: the insets show the dependence of amplitude $(\triangle \mathrm{A})$ of abnormal band in the CD spectrum $(\lambda=505 \mathrm{~nm})$ of dispersion on DOX concentration. $\Delta \mathrm{A}_{505} \times 10^{-6}$ optical units, $\mathrm{L}=1 \mathrm{~cm}$

The particles of the "classic" cholesteric were formed as a result of phase exclusion of DNA molecules from aqueous-salt solution with PEG concentration $170 \mathrm{mg} \cdot \mathrm{ml}^{-1}$. The mean distance between DNA molecules in particles of dispersion was about 3,5 nm and the "fingerprint" texture was typical for the phases formed from such particles. The DNA dispersion, the particles of which have "re-entrant" cholesteric struc- ture $\left(\mathrm{C}_{\mathrm{PEG}}=240 \mathrm{mg} \cdot \mathrm{ml}^{-1}\right)$, was obtained from particles with hexagonal packing of DNA molecules as a result of their heating to $80{ }^{\circ} \mathrm{C}$ and cooling down to $22{ }^{\circ} \mathrm{C}$. In the case of particles with "re-entrant" cholesteric structure, the mean distance between DNA molecules was about $2,5 \mathrm{~nm}$ and no specific "fingerprint" texture was obtained. 
The particles formed in both cases were handled of DOX under identical conditions (Fig. 4, $A$ and Fig. 4, $B$ ). The comparison of Fig. 4, $A$ and Fig. 4, $B$ allows to point out some relevant facts.

1) In both spectra (classical and reentrant cholesterics) there is the abnormal band in the UV region of absorption of DNA nitrogen bases, and additional abnormal band corresponding to the electron transition in DOX molecules $(\lambda \sim 500 \mathrm{~nm})$. The band in visible region of the spectrum occurs practically "at the moment" of the treatment of both types of DNA dispersions by DOX solution. This band shows that DOX molecules interact with DNA.

2) The negative sign of the band in $C D$ spectrum in the DOX absorption range coincides with the sign of the band in the DNA nitrogen bases absorption region. It means that the angle of inclination of DOX molecules in relation to the cholesteric structure axis of dispersion particles coincides with inclination angle of DNA nitrogen bases to this axis. Such situation is possible in case, when DOX molecules are intercalated between nitrogen base pairs of DNA molecules ordered in quasinematic layers of dispersion particles.

3) According to SAXS results, the increase of solution osmotic pressure at the rise of PEG concentration results in the decrease of mean distance between DNA molecules in quasinematic layers of dispersion particles. Simple theoretical arguments suggest that such decrease in the distance between DNA molecules increases the twist angle of quasinematic layers. It increases also the abnormal band amplitude in CD spectrum of cholesteric DNA dispersions.

Indeed, in the case of DNA dispersion with the "re-entrant" cholesteric structure and relatively small intermolecular distance in quasinematic layers $\left(\mathrm{C}_{\mathrm{PEG}}=\right.$ $240 \mathrm{mg} \cdot \mathrm{ml}^{-1}$ ), the amplitude of the abnormal band in DNA absorption region noticeably exceeds the value characteristic for "classic" cholesteric formed at $\mathrm{C}_{\mathrm{PEG}}=170 \mathrm{mg} \cdot \mathrm{ml}^{-1}$ (Fig. 2).

4) There is evident correlation between the band in the CD spectrum of the absorption of DNA chromophores and absorption band of intercalated chromophores [26]. Therefore, the increase in amplitude in the DNA absorption region will be accompanied by the rise of a similar band in the visible range of CD absorption spectrum of DOX chromophores.

The dependence of band amplitudes in CD spectra in visible region on DOX concentration in solution is shown in the insets on Fig. 4, $A$ and $B$. The comparison of Fig. 4, $A$ and $B$ evidences that optical properties of DNA "re-entrant" cholesteric structure exceed similar parameter of initial cholesteric. A higher amplitude value of the band in region of DNA absorption (Fig. 4, $B$ ) corresponds to a higher equilibrium value of the band in the DOX absorption range (at $\lambda=505 \mathrm{~nm}$ ). Such correlation is possible only in case of conservation of parameters of the B-form of DNA molecules, which is required for DOX intercalation.

The dependences shown above demonstrate that in both cases DOX molecules bind to the base pairs of DNA molecules ordered in quasinematic layers. The binding saturates when DOX complexes occupy all sites in DNA molecules accessible to the intercalation.

The further rise of DOX concentration practically does not result in the increase of the band in visible region of $C D$ spectrum. It means that according to $C D$ spectroscopy, only DOX molecules intercalated between base pairs of DNA molecules ordered in quasinematic layers of dispersion particles are visible.

The shown in Fig. 4 the CD spectra are characteristic for the cholesteric structure of DNA molecules in the B-form.

The binding of DOX (or its structural analogue - DAU, Fig. 3) to the LC dispersions formed of ds polynucleotide - poly $(\mathrm{I}) \times \operatorname{poly}(\mathrm{C})$ molecules in the A-form is not accompanied by any changes in the CD spectra [45]. This result is evident because the intercalation complexes of DOX with polynucleotides of the A-family cannot be formed.

We conclude that the "re-entrant" cholesteric structure obtained at heating of particles with initial hexagonal packing of DNA molecules at $\mathrm{C}_{\mathrm{PEG}}=$ $240 \mathrm{mg} \cdot \mathrm{ml}^{-1}$ retains the parameters of the B-form of DNA.

The further increase of PEG concentration in the solution is accompanied by change in properties of "re-entrant" cholesteric structure, in particular, by the decrease of the abnormal band amplitude (Fig. 2). However, under the indicated requirements, a correct intercalation of DOX between DNA base pairs and correct orientation of DOX in quasinematic layers of dispersion particles becomes impossible.

Results shown in Fig. 4 manifest that heating of the hexagonal structure of ds DNA leads to formation of several types of ordering in the dispersion particles. These particles differ not only by their ability to form "re-entrant" cholesteric structures, but also by parameters of the secondary structure of ds DNA molecules. 
Cross-linking of adjacent DNA molecules ordered in "re-entrant" cholesteric phases

For additional parameters study of ds DNA molecules ordered in quasinematic layers of spatially twisted LC dispersion particles we have applied the well-elaborated approach $[19,46]$ based on transformation of "liquid-like" state of these particles to "rigid" (gel-like) state.

Indeed, the adjacent ds DNA molecules in quasinematic layers of dispersion particles exist in "dissolved" state and there is free space between them. The molecules of substances ("guests") entering the free space due to diffusion can react with chemical groups available on the DNA surface or even form chemical cross-links between DNA molecules. Such cross-linking can result in the formation of spatial structure involving all DNA molecules ordered in quasinematic layers of LC particle and having very high molecular mass. This structure will be incompatible with PEG-containing solution. It means that the crosslinking of adjacent DNA molecules will lead to transformation of single LC particle from "liquid-like" to "rigid" (gel-like) state.

The "rigid" ds DNA particles can be immobilized on the surface of nuclear membrane filter and their properties can be studied by atomic force or electron microscopy.

In fact, this approach is similar to gelation due to formation of unordered artificial chemical crosslinks between adjacent molecules of polymers. However, in our case, gelation should be realized in such a way that the spatial helical structure of ds DNA LC particle is preserved.

To create cross-links between adjacent ds DNA molecules we used anthracycline antibiotics again. These antibiotics can form so-called "external" complexes with nucleic acids of B- and A-families. Upon formation of an "external" complex, the reactive groups of DOX prove to be available for chemical reactions.

The anthracyclines can form chelate complexes with bivalent metal ions like zinc, cadmium, nickel and so forth. Chelate complexes produced by bivalent copper ions are of particular interest. The interest is attracted by the fact that the resulting chelate complexes have planar structures on account of the electronic structure of bivalent copper ion [47-49] and the spatial structure of anthracycline aglycons. In the case of appropriate bidentate ligands, complexation may result in formation of a flat polymeric chain (polymeric chelate cross-link) comprising of up to 10 sequen- tially arranged molecules cross-linked by bivalent copper ions [50, 51].

An example of a scheme of polymeric chelate cross-link formed between two artificial molecules shown in fig. 5 [19]. Application of this scheme to ds DNA case permits to formulate some important practical requirements.

1) In order to form polymeric cross-links between adjacent ds DNA molecules in quasinematic layer, one has to use chemical groups of compounds "immersed" in DNA wide groove and spatially fixed here.

2) The sites of the "begining" and "end" of such cross-links must be disposed at adjacent ds DNA molecules that is, they should link these molecules. Taking into account the mean distance between ds DNA molecules, these cross-links can be named "nanobridges."

3) The helical structure of ds DNA molecules restricts the possible cross-links between them. Indeed to form cross-links between the same groups it is necessary to turn one DNA molecule around its long axis on $180^{\circ}$ (see Fig. 5). It is means that cross-linking can only be achieved at a certain particular arrangement of two adjacent ds DNA molecules in quasinematic layers of CLCD particles, which have similar sterical parameters, i.e., they are spatially "synchronized".

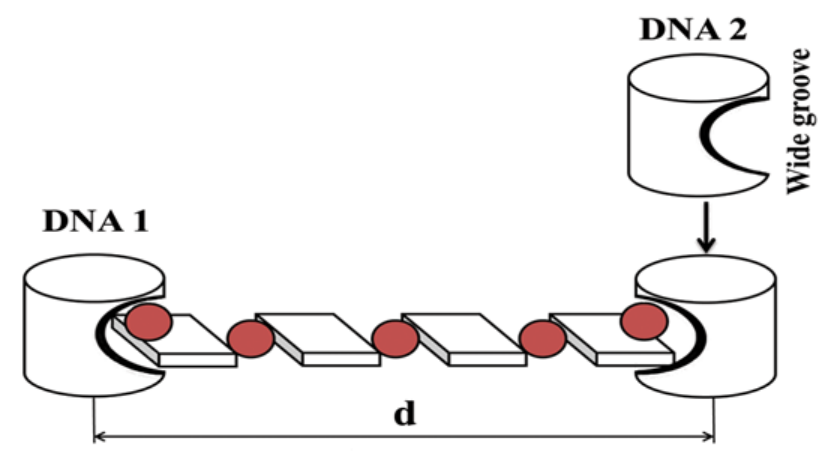

Fig. 5. Structure of extended polymeric chelate complex formed between similar sites in two adjacent ds DNA molecules (1 and 2). The cross-linking is realized only at a certain arrangement of ds DNA molecules in quasinematic layers of CLCD particles. Hypothetically, DNA molecule (2) can be turned around its long axis on $180^{\circ}$, i.e., molecules 1 and 2 are spatially "synchronized". Complex consists of anthracycline molecules linked by metal ions

4) For sterical matching of two parallel ds DNA molecules, a certain distance between these molecules in quasinematic layer is needed (hence, some degree of diffusion freedom for ds DNA molecules). Howe- 
ver, a very dense packing of adjacent ds DNA molecules in quasinematic layers will restrict their spatial matching. Under these conditions, the formation of extended cross-links between the same groups of molecules is simply impossible. Hence, formation of extended cross-links between adjacent ds DNA molecules in quasinematic layers could be realized between molecules that possess intact secondary structures, fixed on spatial positions at concrete intermolecular distances.
5) Let us consider the case when the long axis of polymeric chelate cross-link is perpendicular to the long axis of adjacent ds DNA molecules. Then, we should expect the emergence of abnormal band in the CD chromophore spectrum.

The cross-linking ds DNA molecules in the particles with cholesteric and "re-entrant" cholesteric structures were made by means of the scheme illustrated in Fig. 6.

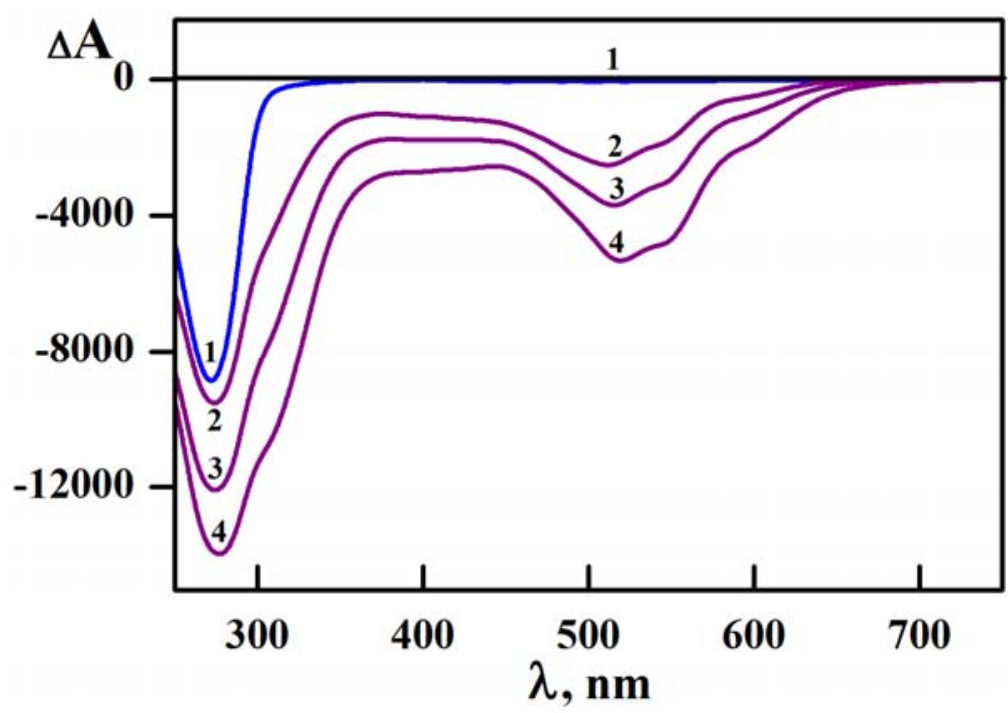

Fig. 6. The CD spectra of the ds DNA CLCD formed in aqueous-salt PEG-containing solution taken after thermal training (curve 1) and successively processing by fixed $\mathrm{DOX}$ and $\mathrm{CuCl}_{2}$ concentrations (curves 2-4).

Curves 2-4 taken in 2.5, 14 and 38 min after treatment of (DNA-DOX) cholesteric dispersion by $\mathrm{CuCl}_{2} \mathrm{Solution}$ respectively.

$\mathrm{C}_{\mathrm{DNA}}=10 \mu \mathrm{g} \cdot \mathrm{ml}^{-1}, \mathrm{C}_{\mathrm{PEG}}=180 \mathrm{mg} \cdot \mathrm{ml}^{-1}, 0.3 \mathrm{M} \mathrm{NaCl}+0.002 \mathrm{M} \mathrm{Na}^{+}$-phosphate buffer,

$\mathrm{C}_{\mathrm{DOX}}=34.14 \times 10^{-6} \mathrm{M}, \mathrm{C}_{\mathrm{Cu} 2+}=19.8 \times 10^{-6} \mathrm{M}$.

$\Delta \mathrm{A}=\left(\mathrm{A}_{\mathrm{L}}-\mathrm{A}_{\mathrm{R}}\right) \times 10^{-6}$ optical units, $\mathrm{L}=1 \mathrm{~cm}$

The LC dispersion particles with cholesteric packing of ds DNA molecules were obtained by mixing of aqueous-salt solution of ds DNA and PEG and "thermal training" of this mixture. We induced the formation of DOX "external" complexes (i.e. extDOX) with ds DNA by treatment of this mixture by DOX, the concentration of which exceeds an equilibrium value (Fig. 4). Then, the obtained dispersion of (ds DNA-extDOX) complex was handled by solution with fixed $\mathrm{CuCl}_{2}$ concentration.

Figure 6 shows the CD spectra taken after definite periods of time. One can see that the addition of $\mathrm{CuCl}_{2}$ solution to (ds DNA-extDOX) complex leads to manifold increase in the abnormal band amplitude at $\lambda \sim 510 \mathrm{~nm}$ typical of a long-wave electronic transition of DOX chromophores. The amplification of this band means that only after addition of $\mathrm{CuCl}_{2}$ solution (curves 2-4), a new mode of fixation of DOX molecules in quasinematic layers of LC dispersion is appeared. (We do not consider the alteration in the CD spectrum in UV region due to the existence of a few electronic transitions in this region of the spectrum).

The increase of the amplitude in the CD absorption spectrum of DOX chromophore is related to the formation of (extDOX- $\left.\mathrm{Cu}^{2+}\right)$ complexes. The complexes are fixed nearby adjacent ds DNA molecules ordered in quasinematic layers of dispersion particles. The matter is that the reactive groups of intercalated DOX molecules are "chemically inert" (see above).

Taking into account that the mean distance between the intact ds DNA molecules (B-form) in cholesteric dispersion particles formed at $\mathrm{C}_{\mathrm{PEG}}=180 \mathrm{mg} \cdot \mathrm{ml}^{-1}$ 
is equal to about $3,4 \mathrm{~nm}$, the (extDOX- $\mathrm{Cu}^{2+}$ ) complexes should possess an extended spatial structure, i.e. these complexes should form cross-links.

These cross-links have planar chelate structures. Stabilization of the cross-links is achieved by rigid fixation of the $\left[-\left(\mathrm{Cu}^{2+}\right.\right.$-extDOX $\ldots-\ldots$ extDOX- $\left.\left.\mathrm{Cu}^{2+}\right)-\right]$ chelate system between two adjacent DNA molecules, i.e., the final spatial system looks like [DNA-extDOX$\left(\mathrm{Cu}^{2+} \text {-DOX ...-..DOX-Cu }{ }^{2+}\right)_{\mathrm{n}}-$ extDOX-DNA].

Because the amplified abnormal band in the CD spectrum has a negative sign, the directions of the long axes of planar cross-links are perpendicular to the direction of long axes of ds DNA molecules ordered in quasinematic layers of dispersion particles. In this case, the helical twist of quasinematic layers in dispersion particles leads to the spatial rotation of "colored" cross-links, and they are "visible" by means of CD spectroscopy. If this is the case, one can conclude that the amplitude of abnormal band in CD spectrum of cholesteric dispersion particles depends on the length of cross-links between adjacent ds DNA molecules. In own turns, the length of the cross-links depends on the mean distance between these molecules.

The stability of cross-linked structure is determined by concentration and characteristics of crosslinks (and basically it is independent on the properties of initial PEG-containing solution).

Hence, the osmotic pressure of PEG-containing aqueous-salt solution is not the main factor affecting the character of packing ds DNA molecules in CLCD particle. The created structure can exist not only in solutions with a very low (up to zero) PEG concentration, but also in solutions with low ionic strength. It means that the adjacent ds DNA molecules in quasinematic layers of single dispersion particles are cross-linked by $\left(\mathrm{DOX}-\mathrm{Cu}^{2+}\right)$ complexes, and these complexes stabilize the spatial structure of CLCD particles.

Figure 6 shows that in the case of the intact Bform, the process of cross-linking of adjacent ds DNA molecules takes no longer than $1 \mathrm{~h}$.

The LC dispersion particles with "re-entrant" (R) cholesteric packing of ds DNA molecules were obtained by mixing of aqueous-salt solution of ds DNA and PEG. The CD spectrum of the initial LC dispersion obtained by the phase exclusion of ds DNA molecules from PEG-containing solution $\left(\mathrm{C}_{\mathrm{PEG}}=\right.$ $270 \mathrm{mg} \cdot \mathrm{ml}^{-1}$ ) at room temperature shows the presence of low intensity band in the ds DNA absorption (not shown in this Figure). It confirms formation of dispersion, particles of which possess hexagonal packing of ds DNA molecules at room temperature. The thin layer optical texture of ds DNA phase obtained from these particles does not contain specific peculiarities. Since the distance between ds DNA molecules in the structure formed at $C_{\mathrm{PEG}}=270 \mathrm{mg} \cdot \mathrm{ml}^{-1}$ is small $(2,6 \mathrm{~nm})$, the simplest rationalization of the absence of "fingerprint" texture typical of the classical DNA cholesterics is that the pitch of this structure is so small that cannot be detected by a polarization microscope.

The "thermal training" of this mixture is accompanied by appearance of intense band in $\mathrm{CD}$ spectrum typical of DNA-R structure.

Curve 1 in Fig. 7 represents the CD spectrum after "thermal training" of initial ds DNA dispersion, i.e., after heating to $80{ }^{\circ} \mathrm{C}$ and subsequent cooling to room temperature. One can see that the "thermal training" of the dispersion formed at $\mathrm{C}_{\mathrm{PEG}}=270 \mathrm{mg} \cdot \mathrm{ml}^{-1}$ is accompanied by the appearance of abnormal negative band in CD spectrum at $\lambda=270 \mathrm{~nm}$ of $\mathrm{ds}$ DNA dispersion. However, the amplitude of this band is much smaller in comparison with the amplitude of "classical" DNA cholesterics (Fig. 6). Despite this fact, it confirms the formation of "re-entrant" cholesteric packing of ds DNA molecules in dispersion particles.

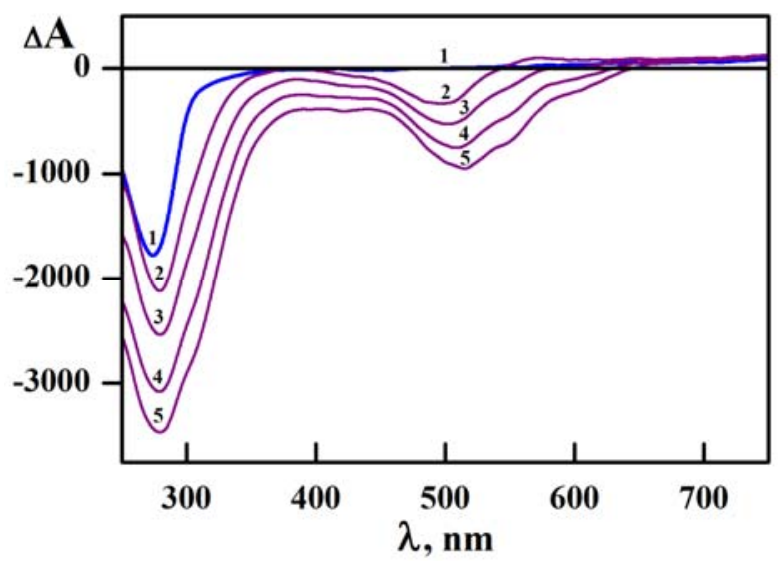

Fig. 7. The CD spectra of the ds DNA CLCD formed in aqueous-salt PEG-containing solution taken after thermal training (curve 1) and successively processing by fixed $\mathrm{DOX}$ and $\mathrm{CuCl}_{2}$ concentrations (curves 2-5).

Curves 2-5 taken in 2.7, 14.8, 28.8 and 47 min after treatment of (DNA-DOX) cholesteric dispersion by $\mathrm{CuCl}_{2}$ solution respectively.

$\mathrm{C}_{\mathrm{DNA}}=10 \mu \mathrm{g} \cdot \mathrm{ml}^{-1}, \mathrm{C}_{\mathrm{PEG}}=270 \mathrm{mg} \cdot \mathrm{ml}^{-1}$, $0.3 \mathrm{M} \mathrm{NaCl}+0.002 \mathrm{M} \mathrm{Na}^{+}$-phosphate buffer, $\mathrm{C}_{\text {DOX }}=34.14 \times 10^{-6} \mathrm{M}, \mathrm{C}_{\mathrm{Cu} 2+}=19.8 \times 10^{-6} \mathrm{M}$. $\Delta \mathrm{A}=\left(\mathrm{A}_{\mathrm{L}}-\mathrm{A}_{\mathrm{R}}\right) \times 10^{-6}$ optical units, $\mathrm{L}=1 \mathrm{~cm}$ 
As above, we produced the DOX "external" complexes (i.e. extDOX) with ds DNA-R by treatment of this mixture by DOX, the concentration of which exceeds an equilibrium value. Then, the obtained dispersion of (ds DNA-R-extDOX) complex was handled by solution with fixed $\mathrm{CuCl}_{2}$ concentration.

The addition of $\mathrm{CuCl}_{2}$ solution to the ds DNA-R treated by DOX leads to the increase in the abnormal band amplitude at $\lambda \sim 510 \mathrm{~nm}$. The reason for the increase in the band amplitude in the CD spectrum of ds DNA-R (Fig. 7, curves 2-5) is formation of the $\left(\right.$ extDOX $\left.-\mathrm{Cu}^{2+}\right)$ cross-links between adjacent ds DNA molecules ordered in quasinematic layers.

Stabilization of cross-links is achieved by rigid fixation of the $\left[-\left(\mathrm{Cu}^{2+}-\mathrm{DOX} \ldots-\ldots\right.\right.$ DOX- $\left.\left.-\mathrm{Cu}^{2+}\right)-\right]$ chelate system between two adjacent DNA-R molecules, i.e., the final system looks like [DNA-R-extDOX$\left(\mathrm{Cu}^{2+}-\text { DOX ...-...DOX-Cu }{ }^{2+}\right)_{\mathrm{n}}$-extDOX-DNA-R].

Comparison of the results presented in Fig. 6 and Fig. 7 shows that, in general, the main peculiarities of CD spectra of ds DNA-R are similar to those of classical ds DNA cholesteric, despite of smaller (about 2,6 $\mathrm{nm}$ ) distance between ds DNA molecules in structure formed at $\mathrm{C}_{\mathrm{PEG}}=270 \mathrm{mg} \cdot \mathrm{ml}^{-1}$. However, one can see that the shape of the band at $\lambda \sim 510 \mathrm{~nm}$ slightly changes.

The increase in PEG concentration up to 280 $300 \mathrm{mg} \cdot \mathrm{ml}^{-1}$ is accompanied by further decrease of the mean distance between hexagonally packed DNA molecules. Under these conditions, the hydration of the DNA molecules is accompanied by the variation of spatial arrangement of the quasinematic layers. Moreover, at high packing density of adjacent DNA molecules in particles of dispersions not only the extent of DNA hydration but parameters of secondary structure of these molecules vary as well.

Let us stress that all changes in the quasinematic layers or in the parameters of DNA secondary structure result in the change of optical properties of LC dispersions.

In agreement with theoretical calculations [26], there is a sharp reduction of amplitude of the abnormal negative band $(\lambda=270 \mathrm{~nm})$ in the CD spectrum of cholesteric dispersions. Figure 8 shows the theoretically calculated dependence of amplitude of abnormal band in the CD spectrum of cholestric dispersion on the parameter $\beta$. The parameter characterizes the dis- ordering extent of DNA molecules in quasinematic layers in particles of dispersions. Even a minor change of this parameter is accompanied by the formation of DNA LC dispersions with very low-intensity of the negative band in $\mathrm{CD}$ spectra.

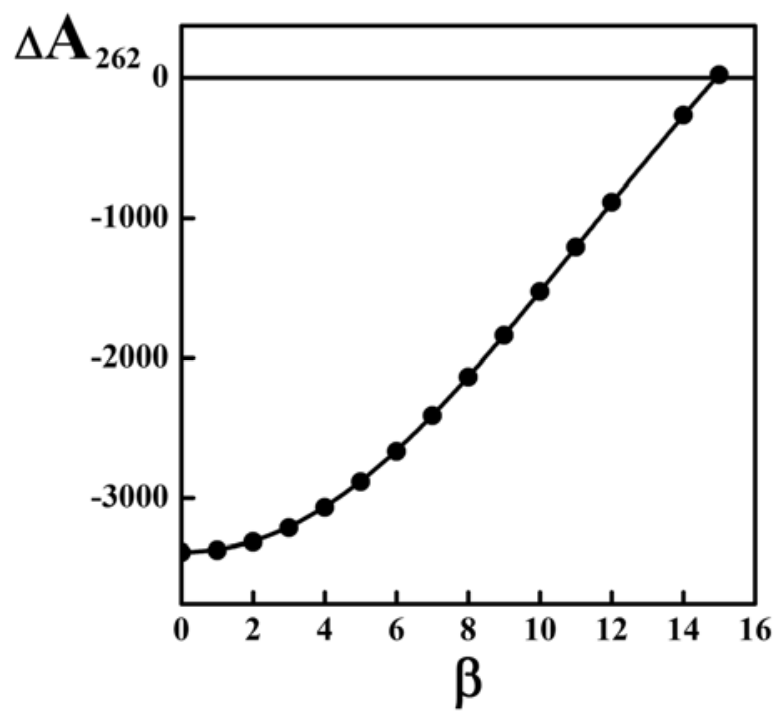

Fig. 8. The theoretically obtained dependence of the amplitude of abnormal band $(\triangle \mathrm{A})$ in the $C D$ spectra $(\chi=262 \mathrm{~nm})$ of CLCD DNA on the parameter $\beta$.

The calculations are made for the "artificial" CLCD of ds DNA with the following parameters: diameter of dispersion particles (D) - $500 \mathrm{~nm}$; the cholesteric pitch $(\mathrm{P})-2,500 \mathrm{~nm}$;

DNA concentration $\left(\mathrm{C}_{\mathrm{DNA}}\right)-10 \mu \mathrm{g} \cdot \mathrm{ml}^{-1}$. $\Delta \mathrm{A}_{262} \times 10^{-6}$ optical units, $\mathrm{L}=1 \mathrm{~cm}$

From this point of view, the data obtained for dispersions formed at $\mathrm{C}_{\mathrm{PEG}}=290 \mathrm{mg} \cdot \mathrm{ml}^{-1}$ are of special interest. These dispersions were formed according to technology described above (see Fig. 6 and Fig. 7), and under the same conditions their CD spectra were registered.

The CD spectra of ds DNA dispersion particles with re-entrant structure formed at $\mathrm{C}_{\mathrm{PEG}}=290 \mathrm{mg} \cdot \mathrm{ml}^{-1}$ after its processing by $\mathrm{DOX}$ and $\mathrm{CuCl}_{2}$ solutions are shown in Fig. 9, $A$. One can see that in the case of formation of "re-entrant" phase at $C_{\mathrm{PEG}}=290 \mathrm{mg} \cdot \mathrm{ml}^{-1}$ and its processing by DOX, the low-intensity band at $\lambda \sim 270 \mathrm{~nm}$ is kept (curve 1). However, the addition of copper ions is accompanied by catastrophic change in the shape of CD spectrum. 
Note that not only the shape of CD spectrum is varied but the response of dispersion of (DNA-DOX) complex to the addition of copper ions (curves 2 and 3 ) does as well. In particular, the negative band ampli- tude at $\lambda \sim 300 \mathrm{~nm}$ increases; in addition there are the low-intensity positive band $\lambda \sim 400 \mathrm{~nm}$, the negative band at $\lambda \sim 500 \mathrm{~nm}$ and the low-intensity positive band at $\lambda \sim 550 \mathrm{~nm}$.
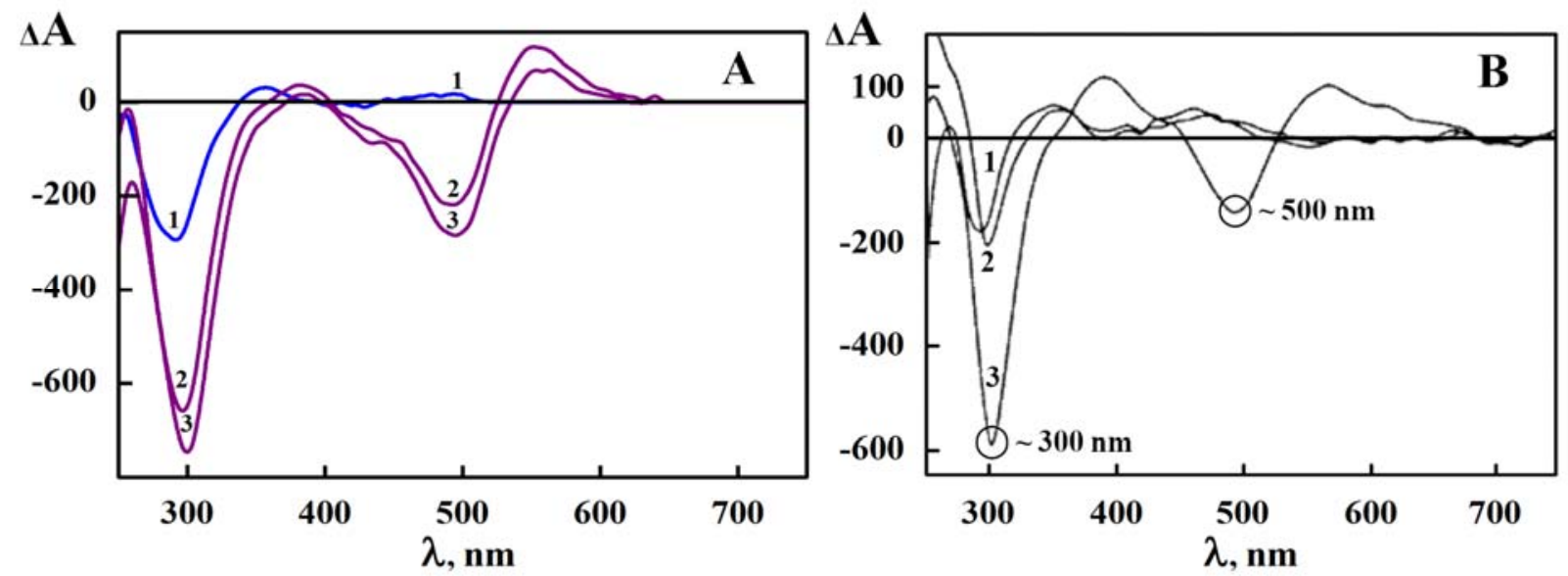

Fig. 9. A: The CD spectra of the ds DNA CLCD formed in aqueous-salt PEG-containing solution taken after thermal training (curve 1) and successively processing by fixed DOX and $\mathrm{CuCl}_{2}$ concentrations (curves 2-3).

Curves 2-3 taken in 2.7 and 21 min after treatment of (DNA-DOX) cholesteric dispersion by $\mathrm{CuCl}_{2}$ solution respectively. $\mathrm{C}_{\mathrm{DNA}}=10 \mu \mathrm{g} \cdot \mathrm{ml}^{-1}, \mathrm{C}_{\mathrm{PEG}}=290 \mathrm{mg} \cdot \mathrm{ml}^{-1}, 0.3 \mathrm{M} \mathrm{NaCl}+0.002 \mathrm{M} \mathrm{Na}^{+}$-phosphate buffer, $\mathrm{C}_{\mathrm{DOX}}=34.14 \times 10^{-6} \mathrm{M}, \mathrm{C}_{\mathrm{Cu2}+}=19.8 \times 10^{-6} \mathrm{M}$. $\Delta \mathrm{A}=\left(\mathrm{A}_{\mathrm{L}}-\mathrm{A}_{\mathrm{R}}\right) \times 10^{-6}$ optical units, $\mathrm{L}=1 \mathrm{~cm}$.

$\boldsymbol{B}$ : The CD spectra of DAU (curve 1) and a DAU solution with addition of linear, noncondensed DNA (curve 2) and $\mathrm{CuCl}_{2}$ (curve 3 ).

$\mathrm{C}_{\mathrm{DNA}} \sim 15 \mu \mathrm{g} \cdot \mathrm{ml}^{-1}, \mathrm{C}_{\mathrm{PEG}}=170 \mathrm{mg} \cdot \mathrm{ml}^{-1}, 0.05 \mathrm{M} \mathrm{NaCl}+0.002 \mathrm{M} \mathrm{Na}^{+}$-phosphate buffer,

$\mathrm{C}_{\mathrm{DAU}}=44 \times 10^{-6} \mathrm{M}, \mathrm{C}_{\mathrm{Cu2}+}=60 \times 10^{-6} \mathrm{M}$.

$\Delta \mathrm{A}=\left(\mathrm{A}_{\mathrm{L}}-\mathrm{A}_{\mathrm{R}}\right) \times 10^{-6}$ optical units, $\mathrm{L}=1 \mathrm{~cm}$

These CD spectra practically have no similarity to the CD spectra arising at the cross-linking of adjacent DNA molecules in dispersion particles with the re-entrant cholesteric structure of complexes (DOX$\mathrm{Cu}^{2+}$ ). It means, that in the case of very high density of hexagonal packing of ds DNA molecules in initial particles and in particles with "re-entrant" structure generated on their basis, the cross-linking of adjacent DNA molecules by (DOX- $\mathrm{Cu}^{2+}$ ) complexes becomes simply impossible sterically.

To compare, the known CD spectrum [52] observable at processing linear not condensed DNA molecules in aqueous-salt PEG solution by DAU (Fig. 3) i.e., structural analogue of DOX, and copper ions is shown in Fig. 9, $B$.

The following facts attract attention.

1) Linear ds DNA molecules in solution of low ionic strength $(0,05)$ are in isotropic state.
2) At treatment of isotropic solution of DNA by DAU and copper ions, we observe the following behavior. The amplitude of the negative band at $\lambda \sim 300$ $\mathrm{nm}$ increases. Besides the new bands appear: the lowintensity positive band at $\lambda \sim 400 \mathrm{~nm}$; the lowintensity negative band at $\lambda \sim 500 \mathrm{~nm}$; and the lowintensity positive band at $\lambda \sim 570 \mathrm{~nm}$. All these changes in CD spectrum specify DNA interaction with DAU and copper ions.

3) As DAU molecules, intercalating between DNA base pairs cannot form chelate complexes with copper ions, only DAU molecules forming "external" complexes with DNA can bind these ions. However, in the case of sufficiently large distance between linear DNA molecules and their disorder distribution in space, the cross-linking of adjacent DNA becomes impossible sterically. 
4) The CD spectrum shown in Fig. 9, $B$ is practically similar to the CD spectrum in Fig. 9, $A$.

One can repeat once again the assumption, according to which, at a very high osmotic pressure of PEG-solution the extent of hydration of ds DNA molecules and the distance between these molecules is diminished. The ds DNA secondary structure is "deformed" and it produces disorder in the orientation of the adjacent the DNA molecules. The structural properties of ds DNA molecules become analogous to the properties of flexible linear molecules and the fixation of $\left(\mathrm{DOX}-\mathrm{Cu}^{2+}\right)$ complexes in ds DNA wide grooves can exist. But, under these conditions the cross-linking adjacent ds DNA molecules is not possible.

A few remarks are necessary here.

The shown above changes in the shape of $C D$ spectra are connected to the character of interaction between aqueous-salt solution and ds DNA sugarphosphate chains. In particular, at high osmotic pressure of PEG-containing solution the transition between B- and A-forms of ds DNA (B $\rightarrow$ A transition) characterized locally by a change in base stacking arrangement and globally by a reduction of the rise/base pair from the canonical $3,38 \AA$ (B-DNA) to 2,56 $\AA$ (A-DNA) [53, 54]. Besides, due to reduced water activity and increased intermolecular interactions, the Aform of ds DNA is more stable than the B-form [55]. A dense packing of adjacent A-form of ds DNA molecules in quasinematic layers will restrict the formation of extended cross-links between the same groups of molecules. It is worth to stress that intermolecular interactions, which are different for various solutions, have a fundamental value in the definition of nucleic acid conformations [56, 57].

The change in the CD spectra is related to the $\mathrm{B} \rightarrow$ A transition of ds DNA molecules accompanied by the change of intermolecular interactions of adjacent molecules, and the disorder of these molecules.

It means that the change in the extent of ds DNA hydration allows to observe the whole panel of structural changes [58].

A question on the role of $B \rightarrow A$ transition of ds DNA molecules in solutions with high osmotic pressure and the formation of artificial intermolecular "links" under these conditions requires additional study.

Thus, depending on the solvent osmotic pressure, its temperature and the ds DNA secondary structure, one can expect the multiple re-entrant cholesteric structures.

\section{Conclusions}

We describe our recent experimental measurements of the CD spectra of the ds DNA phases formed at high osmotic pressure of PEG-containing solutions. Special attention is paid to the analysis of the alteration of these spectra as the result of the interaction of antibiotic molecules with DNA nitrogen base pairs and the formation of polymeric cross-links between adjacent DNA molecules.

The abnormal optical properties of new DNA "re-entrant" cholesteric phases formed at elevated temperature and high osmotic pressure of solutions depend on the mean distance between DNA molecules. The reduction of distance between adjacent ds DNA molecules packed in quasinematic layers of dispersion particles may result in the distortion of the DNA secondary structure. Possible distortion of the ds DNA secondary structure at high osmotic pressure of solvent may be accompanied by alteration of shape of abnormal band in CD spectrum or its disappearance. The connecting efficiency of the ds DNA molecules by specific cross-links consisting of anthracycline molecules and copper ions can depend on few parameters: i) peculiarities of DNA secondary structure; ii) intermolecular distances between ds DNA molecules ordered in quasinematic layers of dispersion particles; iii) disorder in the structure of DNA quasinematic layers.

\section{References}

1. Livolant F., Leforestier A. Condensed phases of DNA: structures and phase transitions. Prog. Polym. Sci., 1996, 21 (6), 1115-1164.

DOI: $10.1016 / \mathrm{S} 0079-6700(96) 00016-0$.

2. Kassapidou K., Jesse W., van Dijk J.F., van der Maarel J.R. Liquid crystal formation in DNA fragment solutions. Biopolymers, 1998, 46 (1), 31-37.

DOI: $\quad 10.1002 /($ SICI)1097-0282(199807)46:1<31:: AID-BIP3>3.0.CO;2-Z.

3. Mitov M. Cholesteric liquid crystals in living matter. Soft Matter, 2017, 13 (23), 4176-4209.

DOI: $10.1039 / \mathrm{c} 7 \mathrm{sm} 00384 \mathrm{f}$.

4. Lerman L.S. A transition to a compact form of DNA in polymer solutions. Proc. Natl. Acad. Sci. USA, 1971, 68 (8), 1886-1890. DOI: 10.1073/pnas.68.8.1886.

5. Yevdokimov Yu.M., Skuridin S.G., Lortkipanidze G.B. Liquid-crystalline dispersions of nucleic acids. Liq. Cryst., 1992, 12 (1), 1-16.

DOI: $10.1080 / 02678299208029034$. 
6. Rau D.C., Lee B., Parsegian V.A. Measurement of the repulsive force between polyelectrolyte molecules in ionic solution - hydration forces between parallel DNA double helices. Proc. Natl. Acad. Sci. USA., 1984, 81 (9), 2621-2625. DOI: 10.1073/pnas.81.9.2621.

7. Goldar A., Thomson H., Seddon J.M. Structure of DNA cholesteric spherulitic droplet dispersions. J. Phys.: Condens. Matter, 2007, 20 (3), 035102.

DOI: $10.1088 / 0953-8984 / 20 / 03 / 035102$.

8. Biswas N., Ichikawa M., Datta A., Sato Y.T., Yanagisawa M., Yoshikawa K. Phase separation in crowded micro-spheroids: DNA-PEG system. Chem. Phys. Lett., 2012, 539-540 (29), 157-162.

DOI: $10.1016 /$ j.cplett.2012.05.033.

9. Blinov L.M. Structure and Properties of Liquid Crystal. Dordrecht: Springer Science+Business Media, 2011, 439 p. DOI: $10.1007 / 978-90-481-8829-1$.

10. Leonard M., Hong H., Easwar N., Strey H.H. Soft matter under osmotic stress. Polymer, 2001, 42 (13), 58235827. DOI: $10.1016 / \mathrm{S} 0032-3861(0) 00903-4$.

11. Yasar S., Podgornik R., Valle-Orero J., Johnson M.R., Parsegian V.A. Continuity of states between the cholesteric $\rightarrow$ line hexatic transition and the condensation transition in DNA solutions. Sci. Rep., 2014, 4, 6877. DOI: $10.1038 /$ srep06877.

12. Adamczyk A. Phase transition in freely suspended smectic droplets. Cotton-Mouton technique, architecture of droplets and formation nematoids. Mol. Cryst. Liq. Cryst., 1989, 170 (1), 53-69.

DOI: $10.1080 / 00268948908047747$.

13. Chiccoli C., Pasini P., Semeria F., Zannoni C. Computer simulations of nematic droplets with toroidal boundary conditions. Mol. Cryst. Liq. Cryst., 1992, 221 (1), 19-28. DOI: 10.1080/10587259208037516.

14. Pollard J., Posnjak G., Čopar S., Muševič I., Alexander G.P. Point defects, chirality and singularity theory in cholesteric liquid crystal droplets. Phys. Rev. X, 2019, 9 (2), 021004.

DOI: $10.1103 /$ PhysRevX.9.021004.

15. Yevdokimov Yu.M., Salyanov V.I., Skuridin S.G., Semenov S.V., Kompanets O.N. The CD Spectra of Double-Stranded DNA Liquid Crystalline Dispersions. New York: Nova Science Publisher Inc., 2011, 103 p.

16. Yevdokimov Yu.M., Skuridin S.G., Salyanov V.I., Kats E.I. Hexagonal $\rightarrow$ cholesteric phase transition of DNA molecules in liquid-crystalline dispersion particles. Dokl. Phys. Chem., 2016, 467 (2), 53-55. DOI: $10.1134 / \mathrm{S} 0012501616040035$.

17. Yevdokimov Yu.M., Skuridin S.G., Semenov S.V., Dadinova L.A., Salyanov V.I., Kats E.I. Re-entrant cholesteric phase in DNA liquid-crystalline dispersion particles. J. Biol. Phys., 2017, 43 (1), 45-68.
DOI: $10.1007 / \mathrm{s} 10867-016-9433-4$.

18. Yevdokimov Yu.M., Skuridin S.G., Salyanov V.I., Kats E.I. Anomalous behavior of the DNA liquidcrystalline dispersion particles and their phases. Chem. Phys. Lett., 2018, 707 (9), 154-159.

DOI: $10.1016 /$ j.cplett.2018.07.028.

19. Yevdokimov Yu.M., Skuridin S.G., Salyanov V.I., Semenov S.V., Kats E.I. Liquid-crystalline dispersions of double-stranded DNA. Crystals, 2019, 9 (3), 162189. DOI: $10.3390 /$ cryst9030162.

20. Bomboi F., Romano F., Leo M., Fernandez-Castanon J., Cerbino R., Bellini T., Bordi F., Filetici P., Sciortino F. Re-entrant DNA gels. Natura Commun., 2016, 7, 3191. DOI: $10.1038 /$ ncomms 13191 .

21. Airoldi M., Barone G., Gennaro G., Giuliani A.-M., Giustini M. Interaction of doxorubicin with polynucleotides. A spectroscopic study. Biochemistry, 2014, 53 (13), 2197-2207. DOI: 10.1021/bi401687v.

22. Fiallo M.M., Tayeb H., Suarato A., Garnier-Suillerot A. Circular dichroism studies on anthracycline antitumor compounds. Relationship between the molecular structure and the spectroscopic data. J. Pharm. Sci., 1998, 87 (8), 967-975. DOI: $10.1021 /$ js9704361.

23. Yevdokimov Yu.M., Salyanov V.I., Semenov S.V., Skuridin S.G. DNA Liquid-Crystalline Dispersions and Nanoconstructions. Boca Raton-London-New York: CRC Press (Taylor \& Francis Group), 2012, 304 p.

24. Sonin A.S. Introduction to the Physics of Liquid Crystals. Moscow : Nauka, 1983, 320 p. (book in Russ.).

25. Sundaresan N., Thomas T., Thomas T.J., Pillai C.K.S. Lithium ion induced stabilization of liquid crystalline DNA. Macromol. Biosci., 2006, 6 (1), 27-32.

DOI: $10.1002 / \mathrm{mabi} .200500145$.

26. Semenov S.V., Yevdokimov Yu.M. Circular dichroism of DNA liquid-crystalline dispersion particles. Biophysics, 2015, 60 (2), 188-196.

DOI: $10.1134 / \mathrm{S} 0006350915020177$.

27. Skuridin S.G., Vereshchagin F.V., Salyanov V.I., Chulkov D.P., Kompanets O.N., Yevdokimov Yu.M. Ordering of double-stranded DNA molecules in a cholesteric liquid-crystalline phase and in dispersion particles of this phase. Molecular Biology (Moscow), 2016, 50 (5), 783-790. DOI: 10.1134/S0026893316040129.

28. Cladis P.E. A one hundred year perspective of the reentrant nematic phase. Mol. Cryst. Liq. Cryst. Inc. Nonlinear Opt., 1988, 165 (1), 85-121. DOI: $10.1080 / 00268948808082197$.

29. Cladis P.E. New liquid-crystal phase diagram. Phys. Rev. Lett., 1975, 35, 48. DOI: 10.1103/PhysRevLett.35.48.

30. Cladis P.E. The re-entrant nematic and the compounds of Gray. Liq. Cryst., 1998, 24 (1), 15-19. DOI: $10.1080 / 026782998207532$. 
31. de Jeu W.H. On the nematic, smectic, and reentrant nematic phase in cyanobiphenyls. Solid State Commun., 1982, 41 (7), 529-532.

DOI: $10.1016 / 0038-1098(82) 90192-2$.

32. Bose T.R., Ghose D., Mukherjee C.D., Saha J., Roy M.K., Saha M. Role of end chains in the reentrant behavior of a nonpolar system. Phys. Rev. A, 1991, 43 (8), 4372-4377. DOI: 10.1103/PhysRevA.43.4372.

33. Pyżuk W., Górecka E., Mieczkowski J., Przedmojski J. Phase transitions and reentrant phenomena in liquid crystals having both rigid and flexible intramolecular joints. J. Phys. II France, 1992, 2 (7), 1465-1477. DOI: $10.1051 /$ jp2:1992213.

34. Nagarayan T., Kumar A. Reentrant phase transition in multicomponent liquid mixtures. Phys. Rep., 1994, 249 (3), 135-218. DOI: 10.1016/0370-1573(94)90015-9.

35. Dudowicz I.J., Douglas J.F., Freed K.F. Equilibrium polymerization models of reentrant self-assembly. J. Chem. Phys., 2009, 130 (16), 164905.

DOI: $10.1063 / 1.3118671$.

36. Reinhardt A., Williamson A.J., Doye J.P.K., Carrete J., Varela L.M., Louis A.A. Reentrant phase behaviour for systems with competition between phase separation and self-assembly. J. Chem. Phys., 2011, 134 (10), 104905. DOI: 10.1063/1.3557059 (arXiv:1010.4676v1 [condmat.soft] 22 Oct 2010).

37. Kumar S., Ray D., Abbas S., Saha D., Aswal V K., Kohlbrecher J. Reentrant phase behavior of nanoparticle solutions probed by small-angle scattering. Curr. Opin. Colloid Interface Sci., 2019, 42, 17-32.

DOI: $10.1016 /$ j.cocis.2019.02.010

38. Camerin F., Gnan N., Ruiz-Franco J., Ninarello A., Rovigatti L., Zaccarelli E. Microgels at interfaces behave as $2 \mathrm{D}$ elastic particles featuring reentrant dynamic. Phys. Rev. X, 2020, 10 (3), 031012. DOI:10.1103/PhysRevX.10.031012 (arXiv:2001.06237 [cond-mat.soft].

39. Lebedeva I.V., Popov A.M. Two phases with different domain wall networks and a reentrant phase transition in bilayer graphene under strain. Phys. Rev. Lett., 2020, 124 (11), 116101.

DOI: $10.1103 /$ PhysRevLett.124.116101.

40. Singh S. Phase transitions in liquid crystals. Phys. Rep., 2000, 324 (2-4), 107-269.

DOI: $10.1016 / \mathrm{S} 0370-1573(99) 00049-6$.

41. Quadrifoglio F., Crescenzi V. On the binding of actinomycin and of daunomycin to DNA: A calorimetric and spectroscopic investigation. Biophys. Chem., 1974, 2(1), 64-69. DOI: 10.1016/0301-4622(74)80025-6.

42. Patel D.J., Canuel L.L. Anthracycline antitumor antibiotic nucleic-acid interactions. Structural aspects of the daunomycin poly(dA-dT) complex in solution. Eur.
J. Biochem., 1978, 90 (2), 247-254. DOI: 10.1111/j.1432-1033.1978.tb12597.x.

43. Gabbay E.J., Grier D., Fingerle R.E., Remier R., Lewy R., Pearce S.W., Wilson W.D. Interaction specificity of the anthracyclines with deoxyribonucleic acid. Biochemistry, 1976, 15 (10), 2062-2070.

DOI: $10.1021 / \mathrm{bi00655a006.}$

44. Zunino F., Gambetta R., Di Marco A., Zaccara A. Interaction of daunomycin and its derivatives with DNA. Biochim. Biophys. Acta - Nucleic Acids Protein Synth., 1972, 277 (3), 489-498.

DOI: $10.1016 / 0005-2787(72) 90092-5$.

45. Skuridin S.G., Amirova S.R., Grigorenko N.A., Efimov V.S., Lortkipanidze G.B., Zakharov M.A., Yevdokimov Yu.M. Molecular constructions based on doublestranded nucleic acid liquid crystals: formation, properties, practical application. Liq. Cryst. and their Appl., 2003, 3, 48-68.

46. Yevdokimov Y.M., Salyanov V.I., Skuridin S.G., Shtykova E.V., Khlebtsov N.G., Kats E.I. Physicochemical and nanotechnological approaches to the design of "rigid" spatial structures of DNA. Rus. Chem. Rev., 2015, 84 (1), 27-42. DOI: 10.1070/RCR4454.

47. Wells A.F. Cooper, silver and gold. Structural Inorganic Chemistry, 5th ed. Oxford : Oxford University Press, 1984, Ch. 25, 1097-1148.

48. Bersuker I.B. The Jahn-Teller Effect and Vibronic Interactions in Modern Chemistry. New York-London: Plenum Press, 1984, 319 p.

49. Basolo F., Pearson R.G. Mechanisms of Inorganic Reactions: A Study of Metal Complexes in Solution, 2nd ed. New York: John Wiley \& Sons, Inc., 1967, 701 p.

50. Kaneko M., Tsuchida E. Formation, characterization and catalytic activity of polymer-metal complexes. J. Polym. Sci.: Macromol. Rev., 1981, 16, 397-522. DOI: $10.1002 /$ pol.1981.230160107.

51. Coble H.D., Holtzclaw H.F. Chelate polymers of copper (II) various dihydroxyquinoid ligands. J. Inorg. Nuclear Chem., 1974, 36 (5), 1049-1053.

DOI: $10.1016 / 0022-1902(74) 80211-3$.

52. Zakharov M.A., Sokolovskaya L.G., Nechipurenko Yu.D., Lortkipanidze G.B., Evdokimov Yu.M. Formation of nanoconstructions based on double-stranded DNA molecules. Biophysics, 2005, 50 (5), 721-727.

53. Hormeno S., Moreno-Herrero F., Ibarra B., Carrascosa J.L., Valpuesta J.M., Arias-Gonzalez J.R. Condensation prevails over B-A transition in the structure of DNA at low humidity. Biophys. J., 2011, 100 (8), 2006-2015. DOI: 10.1016/j.bpj.2011.02.049.

54. Piškur J., Rupprecht A. Aggregated DNA in ethanol solution. FEBS Lett., 1995, 375 (3), 174-178. DOI: 10.1016/0014-5793(95)01206-T. 
55. Sanyal D. Phase transition between A and B forms of DNA: A free-energy perspective. Phys. Rev. E Stat. Nonlin. Soft Matter Phys., 2010, 81 (3), Pt 1, 032901. DOI: $10.1103 /$ PhysRev E.81.032901.

56. Lavalle N., Lee S.A., Rupprecht A. Counterion effects on the physical properties and the A to B transition of calf thymus DNA films. Biopolymers, 1990, 30 (9-10), 877-887. DOI: $10.1002 /$ bip.360300903.

57. Lavalle N., Lee S.A., Flox L.S. Lattice-dynamical model of crystalline DNA: Intermolecular bonds the A to B transition. Phys. Rev. A, 1991, 43 (6), 3126-3130. DOI: $10.1103 /$ PhysRevA.43.3126.
58. Studdert D.S., Patroni M., Davis R.C. Circular dichroism of DNA: temperature and salt dependence. Biopolymers, 1972, 11 (4), 761-779.

DOI: $10.1002 /$ bip.1972.360110404.
Поступила 5.04.2021 2. Received 5.04.2021 Принята 12.05.2021 2. Accepted 12.05.2021 